\title{
MIGRANTS ARE LOSING INTEREST IN RUSSIA ${ }^{1}$ Yu.Florinskaya, N.Mkrtchan
}

According to the split year data, in 2015 positive migration balance in Russia will be below 2013-2014 indicators. Herewith, mobility of the Russian population does not remain at a low level: the scale of internal migration captured by statistics will exceed four million persons. It will be higher than in the 2000s and will reach the 1980-1990s level. The number of foreign labor migrants starts to fall. This data can already be treated as a loss of interest in the Russian labor market emanating from a small part of labor migrants. Looking forward, the number of foreign citizens from EEU member states will remain high in Russia and migration from other CIS member states will be falling. In the meantime, the procedure for foreign workers' legalization on the Russian labor market is getting worse in $2015^{1}$.

\section{Long-term migration}

Captured by the Russia statistics cross-border migration upward trend over recent years (since 2011) seems to be close to terminate in 2015. If in 2011 the number of arrivals to Russia went up by $86 \%$, in $2012-2014$ - by $15-20 \%$ annually, than in the intervening eight months of 2015, it has grown by $7.5 \%$ in comparison with the corresponding period of the previous year. The number of departures continues increasing but also at a slow pace than in previous years: by $15.9 \%$ over January-August against the same period of 2014 (Fig. 1).

At the present stage of the demographic situation in Russia when the results of the natural migration of the population are balancing at virtually zero, cross-border migration practically totally ensures population growth at the level of 250-300 thousand persons annually. According to the split year data, it is prematurely to draw definitive conclusions regarding a decline of

1 This paper was originally published in Online Monitoring of Russia's Economic Outlook No.16.

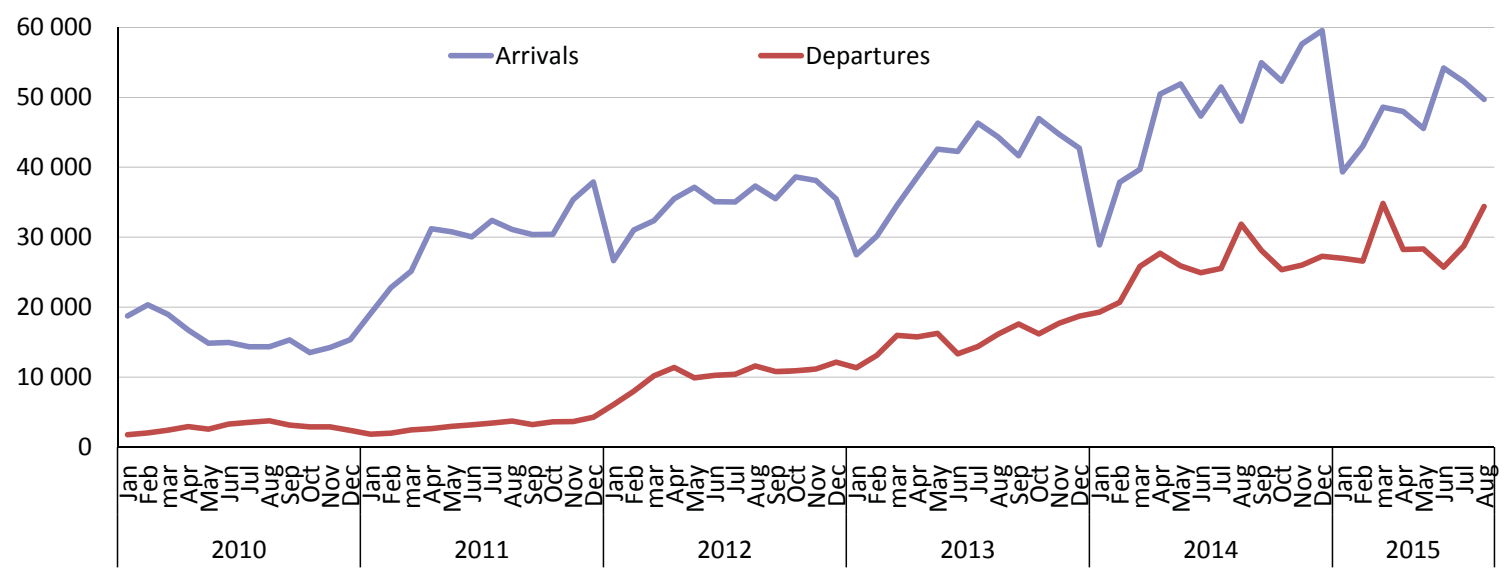

Fig. 1. Cross-border migration to Russia, 2010-2015, monthly data, persons 
the positive migration balance in Russia. However, its indicators are obviously below 2013-2014 levels. Changes in the migration balance observed with major migration partners was differently directed in 2015 (Table. 1).

Table 1

\section{NET CROSS-BORDER MIGRATION, JANUARY-AUGUST 2014 AND 2015,} THOUSAND PERSONS

\begin{tabular}{|l|c|c|}
\hline & 2014 & 2015 \\
\hline Cross-border migration, total & 142.9 & 131.4 \\
\hline With CIS member states & 135.4 & 128.8 \\
\hline Azerbaijan & 9.1 & 7.1 \\
\hline Armenia & 16.4 & 14.3 \\
\hline Belorus & 4.5 & 2.8 \\
\hline Kazakhstan & 24.8 & 20.6 \\
\hline Kirgizstan & 10.4 & 4.2 \\
\hline Moldova & 10.7 & 10.8 \\
\hline Tajikistan & 11.8 & 4.6 \\
\hline Turkmenistan & 1.2 & 1.0 \\
\hline Uzbekistan & 26.6 & -15.0 \\
\hline Ukraine & 36.1 & 93.6 \\
\hline With far-abroad countries & 6.1 & 2.6 \\
\hline
\end{tabular}

Source: Rosstat, current registration data.

In light of the crisis in Ukraine, increase in migration balance with this country is followed by a negative migration balance with Uzbekistan, Tajikistan and Kirgizstan. Whether migration inflow from Ukraine will be growing in the months to come will depend on the situation in the eastern regions of Ukraine and whether the population which left those regions in search of asylum in Russia will repatriate. In the event, there is no mass repatriation of displaced persons to Ukraine then, even without increased migration between the two countries, Russia can get significant increase of arrivals as a result of delayed residence registration.

Russia preserves a small positive migration balance with far-abroad countries, but it is ensured by post-Soviet countries falling in this category: Georgia and the Baltic states. Russia has a negative migration balance with many other far-abroad countries. It is explained by the fact that Russian statistics underestimates the outflow of the population to far-abroad countries $^{1}$.

In 2015 , the number of captured by statistics internal migrations within Russia continued growing: by 86.5 thousand persons or by $3.5 \%$ compared to January-August 2014. In the current year, the number of internal migrations captured by statistics will again exceed four million persons, in other words will be twice as high as in the 2000s and will reach the 1980-1990s levels.

Population continues concentrating in Moscow, Moscow region, Krasnodarsky Krai, Tyumen region and Crimean Federal district. Negative migration balance continues from the North and the East of the country as well as from North Caucasus. There are a few regions in Central Russia and Volga losing population as a result of migration. Despite positive migration balance, in January-August 2015, fifty regions of the country register negative migration balance.

1 See: Denisenko M. Emigration from Russia to far-abroad countries. Demoscope Weekly, 2012, №513-514 http://demoscope.ru/weekly/2012/0513/demoscope513.pdf 
ARRIVALS OF FOREIGN CITIZENS FROM CIS MEMBER STATES TO RF AS OF DATE, PERSONS

\begin{tabular}{|l|c|c|c|c|c|c|c|c|}
\hline & 13.11 .13 & 20.01 .15 & 07.06 .15 & 02.07 .15 & 31.08 .15 & 05.11 .15 & $\begin{array}{c}2015 / \\
2013, \%\end{array}$ \\
\hline Azerbaijan & 621221 & 579493 & 548048 & 555462 & 540164 & 532321 & 86 \\
\hline Armenia & 480640 & 480017 & 525602 & 532299 & 526298 & 504971 & 105 \\
\hline Belorus & 382736 & 517828 & 553633 & 568049 & 609254 & 634861 & 166 \\
\hline Kazakhstan & 609737 & 597559 & 668160 & 694455 & 696050 & 685841 & 112 \\
\hline Kirgizstan & 562357 & 544956 & 508213 & 519801 & 513083 & 526502 & 94 \\
\hline Moldova & 563580 & 561033 & 545516 & 547933 & 528452 & 517692 & 92 \\
\hline Tajikistan & 1145713 & 999169 & 998910 & 1000723 & 978159 & 933155 & 81 \\
\hline Uzbekistan & 2519354 & 2215780 & 2149897 & 2156651 & 2088350 & 1943384 & 77 \\
\hline Ukraine & 1616613 & 2417575 & 2579891 & 2631228 & 2585584 & 2566377 & 159 \\
\hline CIS, total & 8501951 & 8913410 & 9077870 & 9206601 & 9065394 & 8845104 & 104 \\
\hline CIS less Ukraine & 6885338 & 6495835 & 6497979 & 6575373 & 6479810 & 6278727 & 91 \\
\hline
\end{tabular}

Source: FMS of Russia, TsBDUIG.

\section{Temporary migration of foreign citizens}

The number of foreign citizens temporary arriving to Russia is falling: by the end of June 2015, there were 11.1 million foreigners in the country, as of end-August -10.7 million, as of end-September -10.6 million. On the one hand, this fact corresponds to a general trend of reduction of the number of foreigners in the autumn (against spring-summer growth), on the other hand, this year differs from the previous years not only by a weak expression of seasonal trend indicator but by a reduction of its absolute values (number of foreign citizens as of the end of September went down by 10\% below 2014 data and by $6 \%$ below 2013 indicator).

Presumably, this data one can already treat as the loss of interest to the Russian Labor market by a small part of labor migrants (some failed to come in spring-summer for seasonal work and others departed not waiting for positive swings in the economy).

CIS member states still remain major contributors of migrants to the Russian Federation (first of all, labor migrants). They represent $83 \%$ of the total number of foreign citizens or 8.8 million persons (Table 2). However, trends vary within this group of countries: since the beginning of the year, the number of foreign citizens from EEU member states has grown (this refers to Kazakhstan, Belorus and Armenia; number of citizens from Kirgizstan began growing solely since August following this country's accession to EEU and has not exceeded indicators as of the turn of the year). Number of citizens from all other countries year-on-year went down; Ukraine stays separately: the number of its citizens still is rather high and it was increasing until August and then somewhat declined, possibly, due both to a lull in hostilities and to a cancellation of privileged regime of stay for Ukrainian citizens in Russia ${ }^{1}$.

1 On 1 August 2015, it was announced that preferential stay in Russia would be called for the citizens of Ukraine. However, in practice citizens of Ukraine had three months without leaving the Russian territory to process legal status and permits for residence. The last date for Ukrainians to prolong their temporary residence permits terminated on the 31st November 2015 (from then on, Ukrainians who have no work permits were subject to general procedure of stay for not more than 90 days within 180 days). Those who fail to prolong their status before 30 November will violate migration regime with a threat of subsequently being "blacklisted" for entry to Russia. Exception relates solely to displaced persons arriving from the south-eastern regions of Ukraine (city of Donetsk, Donetsk region, city of Lugansk, Lugansk region). Only for them privileges are kept. 
Identified trends have been proven true against the situation in pre-crisis year of 2013. The number of citizens from EEU member states has increased (except Kirgizstan which acceded EEU less than three months ago); significantly increased the number of the Ukrainian citizens, mainly, at the expense of arrivals from Southeast regions from the zone of hostilities; the number of citizens from all other countries have fallen. A significant reduction in the number of citizens was observed from such countries as Uzbekistan ((by $23 \%$ ) and Tajikistan (by 19\%) which have been major sources of labor migration to Russia. On the whole, the number of CIS citizens less Ukraine fell in November 2015 by $9 \%$ compared to early November 2013 and taking account of Ukrainian citizen has grown by $4 \%$.

One may expect that the number of citizens from EEU member states arriving to Russia will remain high in the years to come (possibly, from Kirgizstan it will grow a little) and from other countries it will fall. The number of Ukrainian citizens will start decreasing (unless there is an escalation of hostilities).

If the number of temporary migrants from CIS member states on the whole has barely fell, than the number of foreigners from developed countries: EU, USA and Canada, etc., in other words, from countries which sent both tourists (about $60 \%$ ) and highly qualified specialists, investors and businessmen, etc. has fallen substantially. As of early autumn, the number of foreigners from such countries compared to 2013 has shrunk by half and from the United States, Finland, Great Britain and Spain - by $60 \%$. The number of tourists, private visitors, and commercial, business, study and labor arrivals is falling. This reduction has been steady for over a year and commenced since summer 2014.

One of major 2015 issues is deterioration with legalization of foreign workers on Russian labor market. There is an obvious trend when significant number of foreign labor migrants work in the shadow economy. This fact does not contribute to "healthy" competition between foreign and Russian workers. Over nine months of 2015, total number of issued work patents and permits has fallen by $44 \%$ compared to the same period 2014 (Table 3).

Table 3

NUMBER OF WORK PATENTS AND WORK PERMITS FOR MIGRANTS IN RUSSIA, JANUARY-SEPTEMBER, PERSONS

\begin{tabular}{|c|c|c|c|}
\hline & 9 mo 2015 & 9 mo 2014 & $\begin{array}{c}\text { 2015/2014, } \\
\%\end{array}$ \\
\hline Work permits for foreigners * & 172335 & 965856 & 18 \\
\hline $\begin{array}{l}\text { Work permits for qualified* and } \\
\text { highly qualified specialists }\end{array}$ & 46376 & 121516 & 38 \\
\hline Patents** & 1479673 & 1943810 & 76 \\
\hline Total & 1698384 & 3031182 & 56 \\
\hline
\end{tabular}

* Since 1 January 2015 issued solely to visa-required foreign citizens.

** Since 1 January 2015 issued to visa-free foreign citizens employed by individuals and legal entities.

Source: FMSD of Russia, 1-RD form.

Apparently, radical changes introduced into the migration legislation in 2015 (replacing quotas for work for CIS citizens with work patents) have not produced projected results or, at least, were untimely in the wake of the economic crisis. 